\title{
Effects of estradiol on neural responses to social signals in female túngara frogs
}

\author{
Mukta Chakraborty ${ }^{1, *}$ and Sabrina S. Burmeister ${ }^{1,2, \pm}$
}

\begin{abstract}
Estradiol plays an important role in mediating changes in female sexual behavior across reproductive cycles. In the túngara frog [Physalaemus (=Engystomops) pustulosus], the relationship between gonadal activity and female sexual behavior, as expressed by phonotaxis, is mediated primarily by estradiol. Estradiol receptors are expressed in auditory and motivational brain areas and the hormone could serve as an important modulator of neural responses to conspecific calls. To better understand how estradiol modifies neural responses to conspecific social signals, we manipulated estradiol levels and measured expression of the immediate early gene egr-1 in the auditory midbrain, thalamus and limbic forebrain in response to conspecific or heterospecific calls. We found that estradiol and conspecific calls increased egr-1 expression in the auditory midbrain and limbic forebrain, but in the thalamus, only conspecific calls were effective. In the preoptic area, estradiol enhanced the effect of the conspecific call on egr-1 expression, suggesting that the preoptic area could act as a hormonal gatekeeper to phonotaxis. Overall, the results suggest that estradiol has broad influences on the neural circuit involved in female reproduction, particularly those implicated in phonotaxis.
\end{abstract}

KEY WORDS: Communication, Hormones, Immediate early gene, egr-1, Zenk, Anuran, Physalaemus pustulosus

\section{INTRODUCTION}

In many female vertebrates, estradiol modulates sexual behavior by influencing sensory, motor and motivational brain regions such that sexual behavior occurs when gonadal activity is high. A principal way that estradiol affects sexual behavior is by regulating neural responses in the basal forebrain, which serves to integrate hormonal and sensory information and, in turn, influences motor circuits underlying sexual behavior. For example, the preoptic area in female rats is estradiol sensitive and enhances lordosis by reducing the excitatory neural impulses that project from the preoptic area to the ventral tegmental area (Sakuma, 2015). Estradiol can also impact sensory systems directly. For example, estradiol shapes auditory tuning in midshipmen fish so that, during the breeding season, females are more sensitive to the harmonics in the calls of courting males, which enhances the adaptive coupling of the sender and the receiver for reproductive success (Sisneros, 2009a,b,c; Sisneros et al., 2004). Similar mechanisms of estradiol-dependent

\footnotetext{
${ }^{1}$ Department of Biology, University of North Carolina, Chapel Hill, NC 27599, USA ${ }^{2}$ Curriculum in Neurobiology, University of North Carolina, Chapel Hill, NC 27599, USA.

*Present address: Howard Hughes Medical Institute, Department of Neurobiology, Duke University Medical Center, Durham, NC 27710, USA.

${ }^{\ddagger}$ Author for correspondence (sburmeister@unc.edu)
}

Received 8 July 2015; Accepted 21 September 2015 modulation of acoustic communication circuits are present in birds in response to plasma estradiol (Maney et al., 2006, 2008; Maney and Pinaud, 2011; Sanford et al., 2010) and locally produced neuroestrogens (Krentzel and Remage-Healey, 2015; Pawlisch and Remage-Healey, 2015; Remage-Healey, 2012, 2014; RemageHealey et al., 2010, 2008; Remage-Healey and Joshi, 2012).

Anurans serve as excellent models to explore hormonal effects on auditory plasticity because of the wealth of data available on their courtship behaviors and their associated hormone levels (see reviews by Arch and Narins, 2009; Caras, 2013). In túngara frogs [Physalaemus pustulosus (Cope 1864), also known as Engystomops pustulosus], a primary component of female sexual behavior is phonotaxis, or the approach toward a calling male for the purpose of initiating a mating clasp (amplexus). The expression of selective phonotaxis depends on estradiol (Chakraborty and Burmeister, 2009) and estradiol receptors are expressed widely in auditory, motor and motivational brain regions (Chakraborty and Burmeister, 2010). Furthermore, in the auditory midbrain and parts of the limbic forebrain, estradiol receptor expression is sexually dimorphic (Chakraborty and Burmeister, 2010), suggesting that estradiol is an important modulator of neural circuits underlying female-typical behavior. In addition, injections of human chorionic gonadotropins (hCGs), which stimulate production of gonadal steroids (Lynch et al., 2006; Wu et al., 2001), increase neural responses to conspecific social signals in the auditory midbrain (i.e. torus semicircularis) (Lynch and Wilczynski, 2008), suggesting that one way that estradiol modulates behavioral responses to conspecific calls is through modulation of auditory responses (Lynch and Wilczynski, 2008) or through integration of auditory and motor systems (see Hoke and Pitts, 2012). In fact, Hoke and Pitts (2012) propose that a portion of the auditory midbrain (laminar nucleus of the torus semicircularis) is a critical node for initiating behavioral responses to socially relevant sounds in a reproductive context - a finding also supported by another study (Mangiamele and Burmeister, 2011). Additionally, in female green treefrogs (Hyla cinerea), auditory-evoked multi-unit responses are stronger in unmated females compared with females that have recently mated, suggesting that periods of sexual receptivity are accompanied by enhanced sensitivity of the anuran auditory midbrain to facilitate processing of male advertisement calls (Miranda and Wilczynski, 2009).

To better understand how estradiol promotes phonotaxis in túngara frogs - whether through effects on auditory, motor and/or motivational brain regions - we manipulated estradiol levels by injecting estradiol or an estradiol synthesis blocker (fadrozole) and measured neural responses to conspecific or heterospecific calls throughout the brain. We measured neural responses by measuring expression of the transcription factor egr-1 (early growth response 1; synonymous with zif268, NGFI-A, ZENK). Expression of egr-1 is linked to changes in membrane depolarization (via MAP kinase pathways) and it controls expression of many plasticity-related 
genes (Clayton, 2000). Because of its links to membrane depolarization and synaptic plasticity, the expression of egr-1 is a useful tool for investigating neural responses to behaviorally relevant cues. It also allows measurement of multiple brain regions simultaneously.

\section{MATERIALS AND METHODS}

Hormone treatment and tissue collection

We used adult female túngara frogs from a laboratory stock maintained at the University of North Carolina that was originally derived from natural populations near Rio Píro on the Osa Peninsula in Costa Rica. Photoperiod (12 h:12 h, light:dark) and temperature $\left(28^{\circ} \mathrm{C}\right)$ approximated natural conditions. Because túngara frogs are small, we manipulated hormones through injection rather than surgery, which meant that females had intact gonads that could produce endogenous steroids. Therefore, we began by inducing breeding so that our subjects would start the experiment with low levels of gonadal activity. To do this, females were injected with $500 \mathrm{IU} \mathrm{g}^{-1}$ body mass of hCG and paired with a male and we provided a water dish to stimulate breeding. We collected 48 females that made nests over a period of 7 days for further hormone manipulations. Ten days after the females had made nests, a time when endogenous gonadal steroids are low (Lynch and Wilczynski, 2005), we raised estradiol levels in half of the females and blocked estradiol synthesis in the other half (Fig. 1) as follows. To block estradiol synthesis, females were injected twice with the estradiol synthesis blocker fadrozole $(50 \mu \mathrm{g}$ each injection in $50 \mu \mathrm{l}), 24 \mathrm{~h}$ apart. To raise estradiol, females were injected with saline ( $50 \mu \mathrm{l}$ of $0.9 \%$ sodium chloride) followed $24 \mathrm{~h}$ later by estradiol $\left(0.07 \mu \mathrm{g} \mathrm{g}^{-1}\right.$ body mass in $\left.50 \mu \mathrm{l}\right)$; the purpose of the initial saline injection was to match the number of injections in the fadrozole group. All injections were given in the afternoon

We were not able to collect blood plasma from the females in this experiment to document the effects of our hormone manipulations because blood collection is incompatible with brain collection in this species owing to the small blood volume (i.e. they do not bleed enough following decapitation). However, these hormone manipulations have been validated previously for túngara frogs. Specifically, two injections of fadrozole are effective at inhibiting estradiol synthesis in hCG-treated females (Chakraborty and Burmeister, 2009; Lynch and Wilczynski, 2005). In addition, when measured $24 \mathrm{~h}$ later, a single injection of estradiol at this dose is sufficient to raise estradiol levels above fadrozole-treated females and increases phonotaxis behavior (Chakraborty and Burmeister, 2009). It is important to note that fadrozole would affect both neural and gonadal synthesis of estradiol. Likewise, our estradiol injections likely influence pituitary gonadotropins through negative feedback.

After the final injection, we placed pairs of females, one from each hormone treatment into acoustic isolation chambers; individual females in a pair were maintained separately in individual mesh containers. After an $18 \mathrm{~h}$ acclimation period in the dark, we presented the female pairs with a single exemplar of a conspecific $(N=24)$ or a heterospecific call $(N=24)$ for $30 \mathrm{~min}$ (see below for stimulus details). We interspersed females assigned to each acoustic treatment across days and chambers. Females were rapidly decapitated $1 \mathrm{~h}$ after onset of stimuli, which corresponds to peak accumulation of acoustically induced egr-1 mRNA expression (Burmeister et al., 2008) but occurs before habituation of the egr-1 response is evident (R. M. Glaeser, L. A. Mangiamele and S.S.B., unpublished results). After decapitation, we opened the skull to fix the brains (10 $\mathrm{min}$ in $4 \%$ paraformaldehyde) before removing them. We froze the brains in liquid nitrogen in $2 \mathrm{ml}$ tubes containing Tissue-Tek OCT

\begin{tabular}{|c|c|c|c|c|}
\hline & Day 0 & Day 10 & Day 11 & Day 12 \\
\hline $\begin{array}{l}\text { Estradiol } \\
\text { group }\end{array}$ & $\begin{array}{l}\text { Breeding } \\
(N=24)\end{array}$ & $\begin{array}{c}\text { Saline } \\
\text { injection }\end{array}$ & $\begin{array}{l}\text { Estradio } \\
\text { injection }\end{array}$ & $\begin{array}{l}\text { Conspecific }(N=12) \\
\text { Heterospecific }(N=12)\end{array}$ \\
\hline $\begin{array}{c}\text { Fadrozole } \\
\text { group }\end{array}$ & $\begin{array}{c}\text { Breeding } \\
(N=24)\end{array}$ & $\begin{array}{l}\text { Fadrozole } \\
\text { injection }\end{array}$ & $\begin{array}{l}\text { Fadrozo } \\
\text { injectio }\end{array}$ & Conspecific $(N=12)$ \\
\hline
\end{tabular}

Fig. 1. Timeline of experimental treatments. compound (Sakura, Finetek, Torrance, CA) and stored at $-80^{\circ} \mathrm{C}$ until sectioning. The University of North Carolina Institutional Animal Care and Use Committee (IACUC) approved the experimental procedures.

\section{Acoustic stimuli}

Hormonally manipulated females were presented with a conspecific call recorded in the Osa Peninsula or a heterospecific (Physalaemus enesefae) call from Venezuela (Fig. 2). The túngara frog produces a two-note advertisement call (whine-chuck) (Ryan, 1985) whereas $P$. enesefae only produces a single-note call (whine). The whines of both species are characterized by a downward frequency sweep that spans similar frequencies but they do so with very different time signatures (Fig. 2). Female túngara frogs do not recognize the $P$. enesefae whine as an acceptable sexual signal (e.g. Ryan et al., 2003). In both cases, the call was repeated every $2 \mathrm{~s}$ to reflect the calling rate of $P$. pustulosus and stimulus amplitude was $82 \mathrm{~dB}$ SPL at a distance of $20 \mathrm{~cm}$ from the speaker. The speaker was a midlevel woofer (Misco JC46W-4A, Minneapolis Speaker Company, Minneapolis, MN, USA) that was connected to an AMP Five series monoblock amplifier (Audiosource, Portland, OR, USA) and a Macintosh computer. We controlled playback using ProTools audio software (v7.3; Digidesign, Daly City, CA, USA). Using these exemplars, we have previously demonstrated that the conspecific call, but not the heterospecific call, induces significant expression of egr-l compared with no sound in the auditory midbrain, thalamus and limbic forebrain of túngara frog females (Chakraborty et al., 2010).

\section{Quantification of egr-1 expression}

Brains were sectioned in the transverse plane at $16 \mu \mathrm{m}$ in three series on a cryostat. To localize egr-1 mRNA, radioactive in situ procedures were used as previously described (Burmeister et al., 2008). Briefly, radioactively labeled sense and antisense probes were generated from reverse transcription of a 309-nucleotide subclone of P. pustulosus egr-1. Before hybridization, the tissue was fixed for $10 \mathrm{~s}$ in $4 \%$ paraformaldehyde and washed in phosphate-buffered saline, triethanolamine, acetic anhydride, $2 \times \mathrm{SSC}$ and a series of ethanols. We hybridized the tissue with $90 \mu \mathrm{l}$ of $3.0 \times 10^{5} \mathrm{cpm} \mathrm{ml}^{-1}$ hybridization buffer at $65^{\circ} \mathrm{C}$ overnight. We removed unbound probe with a series of $65^{\circ} \mathrm{C}$ washes, first in $50 \%$ formamide and $2 \times \operatorname{SSC}(1.25 \mathrm{~h})$ followed by two washes in $0.1 \times \mathrm{SSC}(30 \mathrm{~min}$ each). We visualized the bound probe as silver grains by exposing the slides to NTB emulsion diluted 1:1 in distilled water for 14 days at $4^{\circ} \mathrm{C}$, and we visualized cell bodies by staining with thionin. Tissue incubated with the sense probe showed no significant binding above background.

We followed the nomenclature of O'Connell et al. (2011, 2010). egr-1 was measured in brain regions that are known to receive significant auditory input as well as those that are part of the anuran social behavior network (Newman, 1999; O'Connell et al., 2010): the auditory midbrain (principal and laminar nuclei of the torus semicircularis), parts of the thalamus that receive ascending auditory input (posterior, central and anterior thalamic
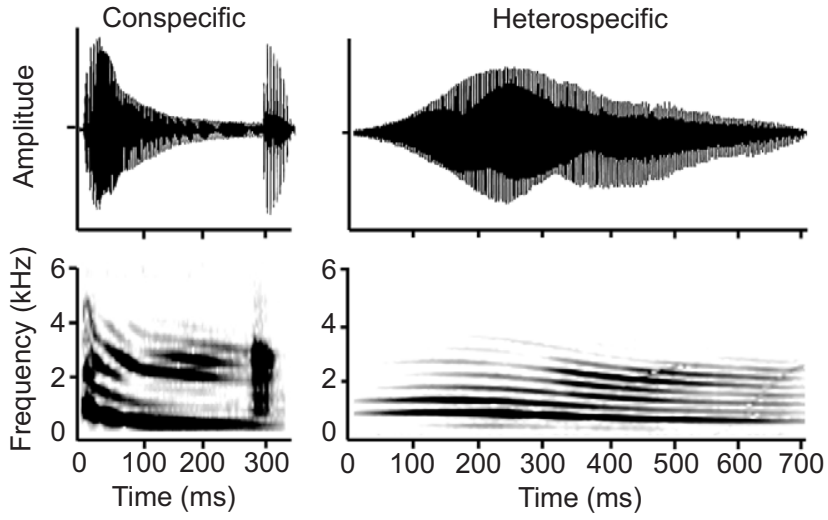

Fig. 2. Waveforms and spectrograms of the call exemplars that we used to represent conspecific (Physalaemus pustulosus) and heterospecific (Physalaemus enesefae) calls. 
Table 1. Statistical results from two-way ANOVAs testing for effects of call type, hormone treatment and their interaction on expression of egr-1

\begin{tabular}{|c|c|c|c|c|c|c|c|}
\hline & \multirow[b]{2}{*}{ d.f. } & \multicolumn{2}{|c|}{ Call type } & \multicolumn{2}{|c|}{ Hormone } & \multicolumn{2}{|c|}{ Call×hormone } \\
\hline & & $F$ & $P$ & $F$ & $P$ & $F$ & $P$ \\
\hline Ptor & 1,30 & 4.7 & 0.04 & 8.9 & 0.006 & 1.9 & 0.18 \\
\hline Ltor & 1,36 & 15.0 & 0.0004 & 13.9 & 0.0007 & 1.6 & 0.22 \\
\hline C & 1,31 & 10.1 & 0.003 & 1.6 & 0.22 & 0.5 & 0.48 \\
\hline A & 1,27 & 11.4 & 0.002 & 0.01 & 0.94 & 0.63 & 0.43 \\
\hline POA & 1,32 & 18.7 & 0.0001 & 6.9 & 0.01 & 4.1 & 0.05 \\
\hline $\mathrm{dMp}$ & 1,28 & 1.9 & 0.18 & 2.7 & 0.11 & 2.1 & 0.16 \\
\hline Acc & 1,32 & 6.0 & 0.02 & 3.8 & 0.059 & 2.8 & 0.11 \\
\hline
\end{tabular}

Expression was measured in the auditory midbrain (Ptor, Ltor), thalamus (P, C, A) and forebrain (POA, Str, Ls, dMp, Acc) of female túngara frogs; $P$ values of 0.1 and less are indicated with bold text. A, anterior nucleus of the thalamus; Acc, nucleus accumbens; $C$, central nucleus of the thalamus; dMp, dorsal part of medial pallium; Ls, lateral septum; Ltor, laminar nucleus of the torus semicircularis; P, posterior nucleus of the thalamus; POA, preoptic area; Ptor, principal nucleus of the torus semicircularis; Str, striatum.

nuclei) and parts of the limbic forebrain that either receive auditory input and/or are directly implicated in modulating phonotaxis (preoptic area, striatum, lateral septum, dorsal part of the medial pallium and nucleus accumbens). Estradiol receptors are expressed at detectable levels in all these brain regions, except for the posterior thalamus (Chakraborty and Burmeister, 2010).
A

Laminar nucleus of torus semicircularis

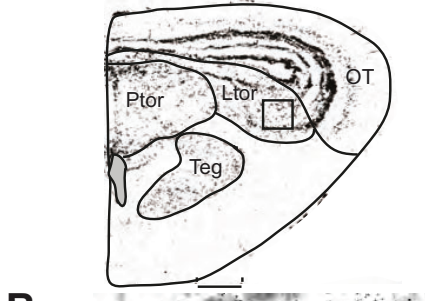

B

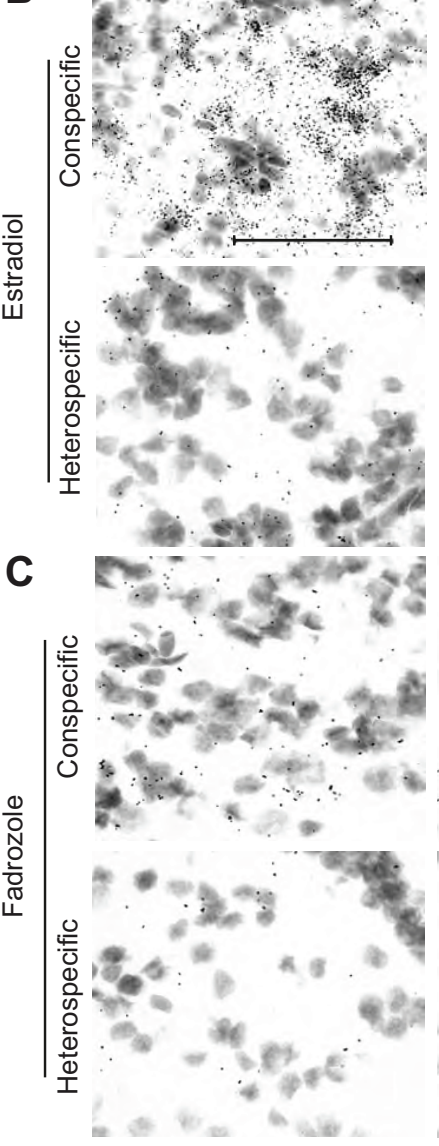

Principal nucleus of torus semicircularis
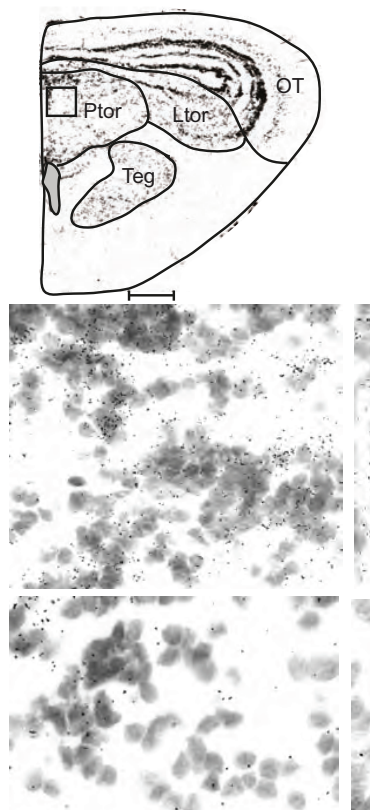

e.
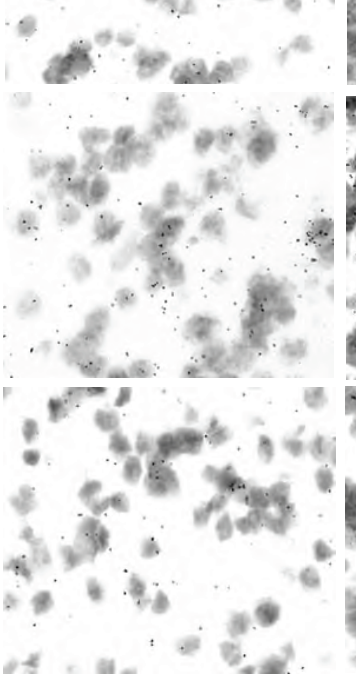

\section{Preoptic area}


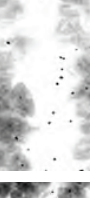

Fig. 3. Variation in silver grain density in response to advertisement calls and hormone treatment in the auditory midbrain and preoptic area of Physalaemus pustulosus. (A) Schematic drawings superimposed on photomicrographs of Nissl-stained sections. Photomicrographs show Ptor, Ltor and preoptic area (POA) from (B) estradiol- and (C) fadrozole-treated frogs. The sampling windows (rectangular boxes) are shown in the schematic drawings. Scale bars: $400 \mu \mathrm{m}(A)$ and $100 \mu \mathrm{m}(B, C)$. $\mathrm{CeA}$, central amygdala; Dp, dorsal pallium; DP, dorsal pallidum; LA, lateral amygdala; Lp, lateral pallium; Ltor, laminar nucleus of the torus semicircularis; MeA, medial amygdala; Mp, medial pallium; Ms, medial septum; OT, optic tectum; Ptor, principal nucleus of the torus semicircularis; Teg, tegmentum; VP, ventral pallidum. 
A

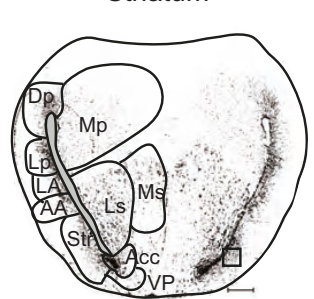

B

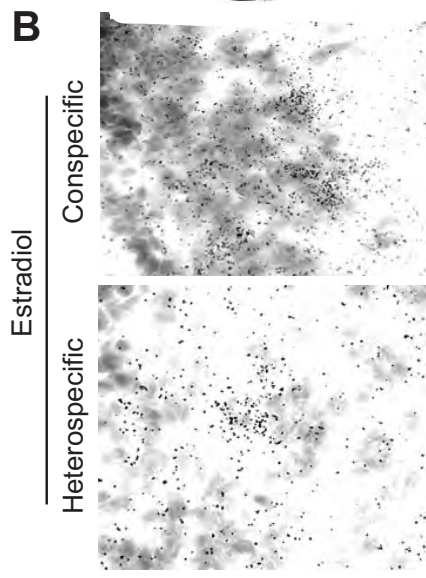

\section{C}

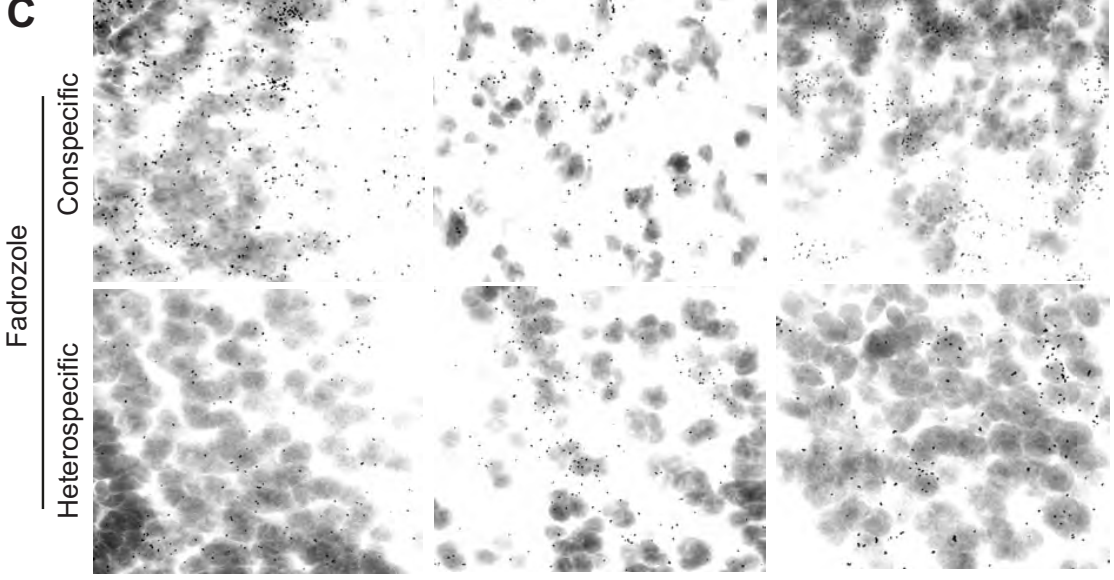

Nucleus accumbens
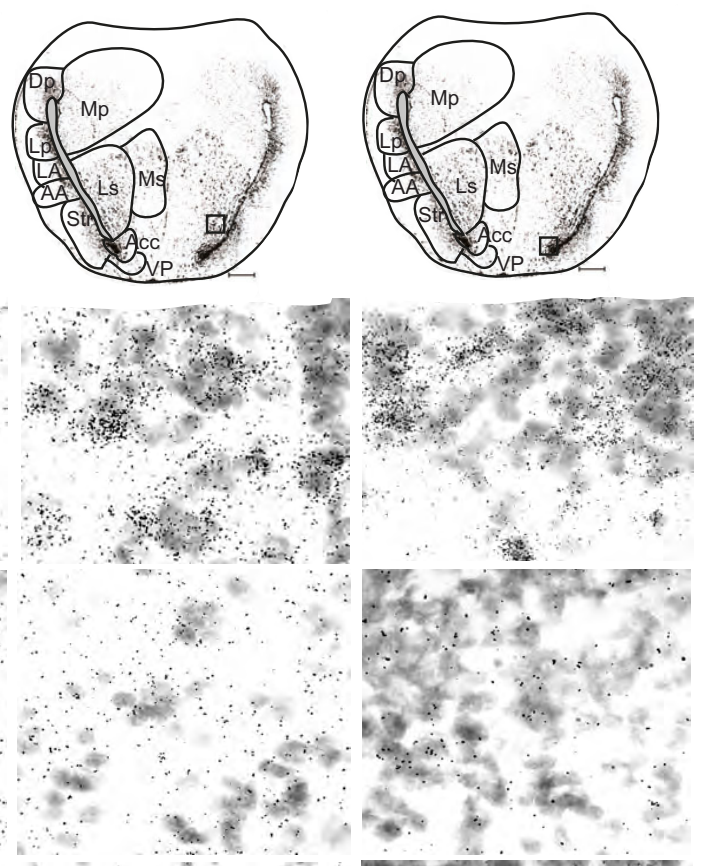

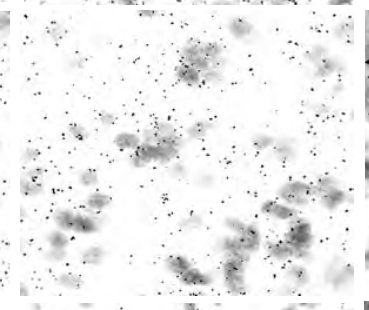

Fig. 4. Variation in silver grain density in response to advertisement calls and hormone treatment in the striatum, lateral septum and nucleus accumbens of Physalaemus pustulosus. (A) Schematic drawings superimposed on photomicrographs of Nissl-stained sections. Photomicrographs show striatum (Str), lateral septum (Ls) and nucleus accumbens (Acc) from (B) estradiol- and (C) fadrozole-treated frogs. The sampling windows (rectangular boxes) are shown in the schematic drawings. Scale bars: $400 \mu \mathrm{m}(\mathrm{A})$ and $100 \mu \mathrm{m}(B, C)$. $\mathrm{AA}$, anterior amygdala; $\mathrm{Dp}$, dorsal pallium; LA, lateral amygdala; Lp, lateral pallium; Ls, lateral septum; Mp, medial pallium; Ms, medial septum; VP, ventral pallidum.

Our quantification method was described previously (Burmeister et al., 2008; Chakraborty et al., 2010) and was derived from Mize (1994), Masseroli et al. (1993) and Lucas et al. (1994). Briefly, for each brain region, an individual's mean was calculated from three brain sections. For each section, we captured three images at $630 \times$ magnification: a color image of Nissl-stained tissue in the region of interest, a blue-filtered image of only the silver grains in the same field of view (grains image) and a blue-filtered image of an area of the slide adjacent to the tissue to represent local background silver grain density (background image). We measured local background silver grain density to account for emulsion thickness, which varies across the slide and influences silver grain density. In the blue-filtered images that we used to measure silver grain density, exposure, brightness and contrast settings were the same for each picture of a given section. ImageJ (http://rsbweb.nih.gov/ij/) was used to convert the grains and background images to binary and to count the silver grains in each image using the 'analyze particles' feature. The number of background silver grains was subtracted from the number of silver grains in the region of interest to obtain the number of silver grains above background per image. We then used the point selection tool in ImageJ to mark and count all visible cells in the color image of the region of interest. Cells were identified visually by their clearly stained soma and the cell counting was performed by experienced individuals who were blind to treatment. Our final measure of egr-1 mRNA expression for each section was the number of silver grains above background per cell. The quality of the brain sections influenced the sample sizes reported for each brain region, as we were unable to obtain data from all individuals in the study for all brain regions sampled.

\section{Statistical analyses}

To test whether hormone treatment, call type or their interaction influenced egr-1 expression, we conducted separate two-way analysis of variances (ANOVAs) for each brain region with call type, hormone treatment and their interaction as between-subjects factors. Although brain regions are not independent of one another, we could not account for covariation among brain regions with a multivariate analysis (e.g. repeated-measures ANOVA) because missing values for individual brain regions would result in the exclusion of most subjects. For the same reason, missing samples prevented us from including 'pair' as a variable in the analyses.

\section{RESULTS}

The conspecific call elicited higher egr-1 expression than the heterospecific call in the auditory midbrain, thalamus and limbic forebrain (main effects for call type, see Table 1, Figs 3-5), demonstrating that conspecific social signals are highly salient elicitors of robust responses throughout the brain, largely independent of hormone status. When compared with fadrozole, injections of estradiol increased egr-l expression in the auditory midbrain and the limbic forebrain, but not in the thalamus (main 

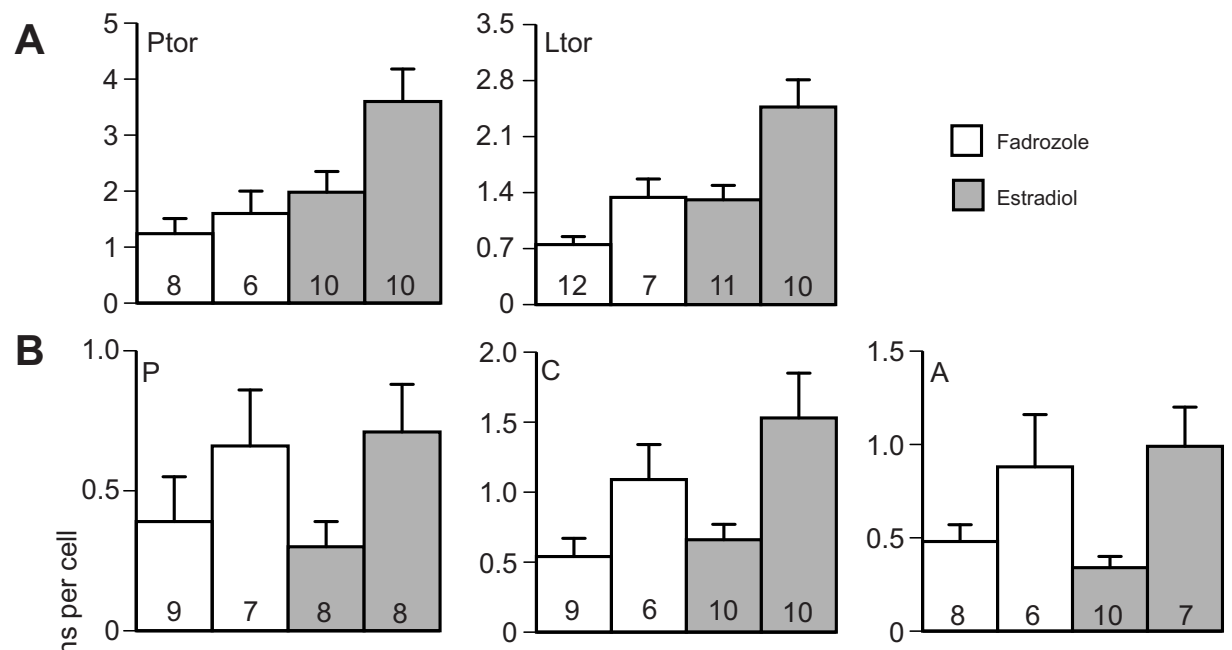

C


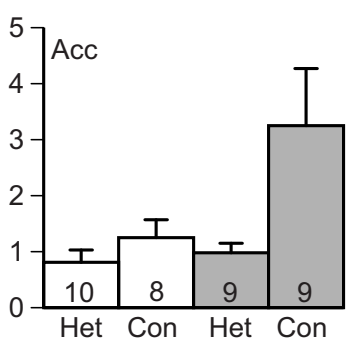

Fig. 5. Effects of call type and hormone treatment on egr-1 gene expression in the auditory midbrain, thalamus and forebrain of Physalaemus pustulosus. Data are shown as mean ( \pm s.e.) silver grains per cell above background in (A) auditory midbrain (Ptor, Ltor), (B) thalamus $(P, C, A)$ and $(C)$ forebrain (POA, Str, Ls, dMp, Acc). Sample sizes for each group are indicated within each column. Het, heterospecific call; Con, conspecific call. $\mathrm{A}$, anterior nucleus of the thalamus; Acc, nucleus accumbens; $\mathrm{C}$, central nucleus of the thalamus; dMp, dorsal part of medial pallium; Ls, lateral septum; Ltor, laminar nucleus of the torus semicircularis; $\mathrm{P}$, posterior nucleus of the thalamus; POA, preoptic area; Ptor, principal nucleus of the torus semicircularis; Str, striatum. effects of hormone treatment, see Table 1, Figs 3-5). That is, estradiol increased egr-1 expression in the midbrain and forebrain independently of the acoustic environment, suggesting that estradiol increases the basal activity of these brain regions.

For most brain regions, the main effects of call type and hormone were independent of one another, and both conspecific calls and estradiol increased egr-1 expression, creating an additive effect. In the preoptic area, however, the effect of call type depended on the hormonal status of the animal $\left(F_{1,32}=4.1, P=0.05\right)$. That is, estradiol enhanced the effect of the conspecific call, suggesting that the preoptic area may have a particularly important role in integrating hormonal and social cues. We observed a similar pattern for the septum, but with less robust statistical support $\left(F_{1,29}=3.5, P=0.07\right)$.

\section{DISCUSSION}

We have previously shown that estradiol is necessary and sufficient for the expression of phonotaxis in the túngara frog (Chakraborty and Burmeister, 2009) and that estradiol receptors show sexually dimorphic expression in the auditory midbrain and parts of the limbic forebrain (Chakraborty and Burmeister, 2010), indicating that estradiol could mediate changes in phonotaxis through direct effects on these brain regions. Consistent with this, we now show that estradiol and conspecific calls both increase egr-1 in the auditory midbrain and parts of the limbic forebrain, including motor (striatum) and motivational (preoptic area, septum, and nucleus accumbens) brain regions. In the preoptic area, the effect of conspecific calls depended on the hormonal status of the animal. Such an effect is consistent with behavioral responses to conspecific calls, which only occur in the presence of estradiol (Chakraborty and Burmeister, 2009), raising the possibility that the preoptic area acts as a hormonal gatekeeper to reproductive behavior in the túngara frog.

Our results for the auditory midbrain parallel a number of studies from other taxa that describe an important role for estradiol in sensory processing of social signals and of audition (Arch and Narins, 2009; Caras, 2013; Earp and Maney, 2012; Maney, 2013; Maney et al., 2006, 2008; Maney and Pinaud, 2011; Petrulis, 2013; Remage-Healey, 2012, 2014; Sanford et al., 2010; Sisneros, 2009c; Tremere et al., 2009; Walpurger et al., 2004; Yovanof and Feng, 1983). In the túngara frog, a previous study showed that hCG, which stimulates production of gonadal steroids (Lynch et al., 2006; Wu et al., 2001), increases egr-1 expression in the laminar nucleus of the torus (Lynch and Wilczynski, 2008). Our findings suggest that the effect observed by Lynch and Wilczynski (2008) was mediated by estradiol and not by direct effects of gonadotropins (Yang et al., 2007) or through changes in other steroids, such as progesterone or androgens. The increased expression of egr-l in response to estradiol might reflect a lower behavioral threshold for approaching calls: when females are nearing oviposition, a time when gonadal hormones are high, they are willing to approach calls that are typically unattractive, although their ability to discriminate among 
calls remains intact (Lynch et al., 2006). The limited electrophysiological data support this conclusion. That is, both reproductive activity (Miranda and Wilczynski, 2009) and estradiol treatment (Yovanof and Feng, 1983) increase auditory responses to sounds in frogs, including biologically irrelevant sounds (noise burst, tones) as well as conspecific calls. There are also broad correspondences between egr-1 (also known as ZENK) expression and electrophysiological activity in songbirds: ZENK expression is selective for conspecific social signals (song) over tones only in the presence of estradiol in female white-throated sparrows (Zonotrichia albicolis) (Maney et al., 2006, 2008; Maney and Pinaud, 2011). Estradiol also enhances auditory encoding of song, sometimes through rapid effects of brain-derived estradiol (Krentzel and Remage-Healey, 2015; Remage-Healey, 2012, 2014; RemageHealey et al., 2010; Tremere and Pinaud, 2011). In zebra finches, the impact of estradiol extends further to the song control system, as estradiol enhances the neural selectivity for the bird's own song (BOS) but not to conspecific songs and fadrozole injections reduce this selectivity (Remage-Healey and Joshi, 2012). Thus, effects of estradiol on auditory processing of social signals are manifest at multiple levels (i.e. MAPK-dependent gene expression and electrophysiological activity) and across vertebrate classes.

An interesting pattern that we observed was that estradiol affected egr-1 expression in the midbrain and limbic forebrain, but not the thalamus. This was in spite of the fact that estradiol receptors are expressed in parts of the thalamus (central and anterior nuclei; Chakraborty and Burmeister, 2010) and the primary auditory afferent to the thalamus (i.e. the torus) was strongly affected by estradiol. Although intriguing, the implications of these results will remain unclear until we have a more complete understanding of the effects of estradiol on electrophysiological responses to conspecific calls. At this time, however, we can conclude that the thalamus appears to lack estradiol-induced auditory plasticity.

We found that estradiol had potent effects on egr-1 expression in the preoptic area and other parts of the limbic forebrain that are thought to modulate socially relevant behavioral responses. While the preoptic area is central to sexual behavior in all vertebrates, a role of the preoptic area in anuran sexual behavior has been less well studied. It has long been known that the anuran preoptic area receives auditory input and that it is sensitive to conspecific calls (Allison, 1992). We recently demonstrated that the anuran preoptic area expresses estradiol receptors (Chakraborty and Burmeister, 2010) and we now show that estradiol modifies its response to conspecific calls ( present study). Together, these data indicate that, like other vertebrates, the anuran preoptic area influences reproductive behaviors by integrating sensory and hormonal information. Furthermore, the fact that the effect of estradiol on the preoptic area mirrors that of estradiol on female phonotaxis suggests that the preoptic area may play a particularly important role in female phonotaxis.

In summary, we found that both conspecific calls and estradiol increased egr-1 expression in the auditory midbrain and limbic forebrain. Together with previous behavioral (Chakraborty and Burmeister, 2009) and electrophysiological studies (Yovanof and Feng, 1983), our results suggest that estradiol could promote selective phonotaxis by lowering the threshold for responses in both the midbrain and limbic forebrain, while highlighting a role for the preoptic area. The effect of estradiol at multiple points in the neural circuit for sexual behavior in túngara frogs is part of a common theme in vertebrates for the influence of steroids on social behavior.

\section{Acknowledgements}

We thank Lauren Eberly, Josh Thompson, Suhana Sarkar, Stuart Jeckel and Mihnea Mangalea for assistance with image analysis, Lisa Mangiamele for the recordings of the $P$. pustulosus calls and Dr Zaida Tárano for the recordings of the $P$. enesefae calls. We also thank Christina Lebonville for help with the experiment.

\section{Competing interests}

The authors declare no competing or financial interests.

\section{Author contributions}

M.C. and S.S.B. conceived and designed experiments, analyzed the data and wrote the paper; M.C. performed the experiments: S.S.B. contributed reagents and materials.

\section{Funding}

This work was supported by the National Science Foundation (NSF) [grant no. IOB 0445682 to S.S.B.] and an NSF doctoral dissertation improvement grant to M.C.

\section{References}

Allison, J. D. (1992). Acoustic modulation of neural activity in the preoptic area and ventral hypothalamus of the green treefrog (Hyla cinerea). J. Comp. Physiol. A 171, 387-395.

Arch, V. S. and Narins, P. M. (2009). Sexual hearing: the influence of sex hormones on acoustic communication in frogs. Hear. Res. 252, 15-20.

Burmeister, S. S., Mangiamele, L. A. and Lebonville, C. L. (2008). Acoustic modulation of immediate early gene expression in the auditory midbrain of female túngara frogs. Brain Res. 1190, 105-114.

Caras, M. L. (2013). Estrogenic modulation of auditory processing: a vertebrate comparison. Front. Neuroendocrinol. 34, 285-299.

Chakraborty, M. and Burmeister, S. S. (2009). Estradiol induces sexual behavior in female túngara frogs. Horm. Behav. 55, 106-112.

Chakraborty, M. and Burmeister, S. S. (2010). Sexually dimorphic androgen and estrogen receptor mRNA expression in the brain of túngara frogs. Horm. Behav. 58, 619-627.

Chakraborty, M., Mangiamele, L. A. and Burmeister, S. S. (2010). Neural activity patterns in response to interspecific and intraspecific variation in mating calls in the túngara frog. PLOS ONE 5, e12898.

Clayton, D. F. (2000). The genomic action potential. Neurobiol. Learn. Mem. $\mathbf{7 4}$, 185-216.

Earp, S. E. and Maney, D. L. (2012). Birdsong: is it music to their ears? Front. Evol. Neurosci. 4, 14.

Hoke, K. L. and Pitts, N. L. (2012). Modulation of sensory-motor integration as a general mechanism for context dependence of behavior. Gen. Comp. Endocrinol. $176,465-471$.

Krentzel, A. A. and Remage-Healey, L. (2015). Sex differences and rapid estrogen signaling: a look at songbird audition. Front. Neuroendocrinol. 38, 37-49.

Lucas, L. R., Mize, R. R. and Harlan, R. E. (1994). Semiquantitative analysis of insitu hybridization results using IMAGE software: a rapid method for counting reduced silver grains over mRNA-positive cells. J. Neurosci. Methods 52 101-109.

Lynch, K. S. and Wilczynski, W. (2005). Gonadal steroids vary with reproductive stage in a tropically breeding female anuran. Gen. Comp. Endocrinol. 143, 51-56. Lynch, K. S. and Wilczynski, W. (2008). Reproductive hormones modify reception of species-typical communication signals in a female anuran. Brain Behav. Evol. 71, 143-150.

Lynch, K. S., Crews, D., Ryan, M. J. and Wilczynski, W. (2006). Hormonal state influences aspects of female mate choice in the Túngara Frog (Physalaemus pustulosus). Horm. Behav. 49, 450-457.

Maney, D. L. (2013). The incentive salience of courtship vocalizations: hormonemediated 'wanting' in the auditory system. Hear. Res. 305, 19-30.

Maney, D. L. and Pinaud, R. (2011). Estradiol-dependent modulation of auditory processing and selectivity in songbirds. Front. Neuroendocrinol. 32, 287-302.

Maney, D. L., Cho, E. and Goode, C. T. (2006). Estrogen-dependent selectivity of genomic responses to birdsong. Eur. J. Neurosci. 23, 1523-1529.

Maney, D. L., Goode, C. T., Lange, H. S., Sanford, S. E. and Solomon, B. L. (2008). Estradiol modulates neural responses to song in a seasonal songbird. J. Comp. Neurol. 511, 173-186.

Mangiamele, L. A. and Burmeister, S. S. (2011). Auditory selectivity for acoustic features that confer species recognition in the túngara frog. J. Exp. Biol. 214, 2911-2918.

Masseroli, M., Bollea, A., Bendotti, C. and Forloni, G. (1993). In situ hybridization histochemistry quantification: automatic count on single cell in digital image. J. Neurosci. Methods 47, 93-103.

Miranda, J. A. and Wilczynski, W. (2009). Female reproductive state influences the auditory midbrain response. J. Comp. Physiol. A 195, 341-349.

Mize, R. R. (1994). Quantitative image analysis for immunocytochemistry and in situ hybridization. J. Neurosci. Methods 54, 219-237. 
Newman, S. W. (1999). The medial extended amygdala in male reproductive behavior. A node in the mammalian social behavior network. Ann. N. Y. Acad. Sci. 877, 242-257.

O'Connell, L. A., Matthews, B. J., Ryan, M. J. and Hofmann, H. A. (2010) Characterization of the dopamine system in the brain of the tungara frog Physalaemus pustulosus. Brain Behav. Evol. 76, 211-225.

O’Connell, L. A., Ding, J. H., Ryan, M. J. and Hofmann, H. A. (2011). Neural distribution of the nuclear progesterone receptor in the túngara frog, Physalaemus pustulosus. J. Chem. Neuroanat. 41, 137-147.

Pawlisch, B. A. and Remage-Healey, L. (2015). Neuroestrogen signaling in the songbird auditory cortex propagates into a sensorimotor network via an 'interface' nucleus. Neuroscience 284, 522-535.

Petrulis, A. (2013). Chemosignals and hormones in the neural control of mammalian sexual behavior. Front. Neuroendocrinol. 34, 255-267.

Remage-Healey, L. (2012). Brain estrogen signaling effects acute modulation of acoustic communication behaviors: a working hypothesis. Bioessays 34 1009-1016.

Remage-Healey, L. (2014). Frank Beach Award Winner: steroids as neuromodulators of brain circuits and behavior. Horm. Behav. 66, 552-560.

Remage-Healey, L. and Joshi, N. R. (2012). Changing neuroestrogens within the auditory forebrain rapidly transform stimulus selectivity in a downstream sensorimotor nucleus. J. Neurosci. 32, 8231-8241.

Remage-Healey, L., Maidment, N. T. and Schlinger, B. A. (2008). Forebrain steroid levels fluctuate rapidly during social interactions. Nat. Neurosci. 11 1327-1334.

Remage-Healey, L., Coleman, M. J., Oyama, R. K. and Schlinger, B. A. (2010) Brain estrogens rapidly strengthen auditory encoding and guide song preference in a songbird. Proc. Natl. Acad. Sci. USA 107, 3852-3857.

Ryan, M. J. (1985). The Túngara Frog, a Study in Sexual Selection and Communication. Chicago: University of Chicago Press.

Ryan, M. J., Rand, W., Hurd, P. L., Phelps, S. M. and Rand, A. S (2003). Generalization in response to mate recognition signals. Am. Nat. 161 380-394.
Sakuma, Y. (2015). Estradiol-sensitive projection neurons in the female rat preoptic area. Front. Neurosci. 9, 67.

Sanford, S. E., Lange, H. S. and Maney, D. L. (2010). Topography of estradiolmodulated genomic responses in the songbird auditory forebrain. Dev. Neurobiol. 70, 73-86.

Sisneros, J. A. (2009a). Adaptive hearing in the vocal plainfin midshipman fish getting in tune for the breeding season and implications for acoustic communication. Integr. Zool. 4, 33-42.

Sisneros, J. A. (2009b). Seasonal plasticity of auditory saccular sensitivity in the vocal plainfin midshipman fish, Porichthys notatus. J. Neurophysiol. 102, 1121-1131.

Sisneros, J. A. (2009c). Steroid-dependent auditory plasticity for the enhancement of acoustic communication: recent insights from a vocal teleost fish. Hear. Res. 252, 9-14.

Sisneros, J. A., Forlano, P. M., Deitcher, D. L. and Bass, A. H. (2004). Steroiddependent auditory plasticity leads to adaptive coupling of sender and receiver. Science 305, 404-407.

Tremere, L. A. and Pinaud, R. (2011). Brain-generated estradiol drives long-term optimization of auditory coding to enhance the discrimination of communication signals. J. Neurosci. 31, 3271-3289.

Tremere, L. A., Jeong, J. K. and Pinaud, R. (2009). Estradiol shapes auditory processing in the adult brain by regulating inhibitory transmission and plasticityassociated gene expression. J. Neurosci. 29, 5949-5963.

Walpurger, V., Pietrowsky, R., Kirschbaum, C. and Wolf, O. T. (2004). Effects of the menstrual cycle on auditory event-related potentials. Horm. Behav. 46, 600-606.

Wu, K. H., Tobias, M. L. and Kelley, D. B. (2001). Estrogen and laryngeal synaptic strength in Xenopus laevis: opposite effects of acute and chronic exposure. Neuroendocrinology 74, 22-32.

Yang, E.-J., Nasipak, B. T. and Kelley, D. B. (2007). Direct action of gonadotropin in brain integrates behavioral and reproductive functions. Proc. Natl. Acad. Sci. USA 104, 2477-2482.

Yovanof, S. and Feng, A. S. (1983). Effects of estradiol on auditory evoked responses from the frog's auditory midbrain. Neurosci. Lett. 36, 291-297. 